Оксана Ліба, кандидат педагогічних наук, стариий викладач кафедри теорії та методики початкової освіти Мукачівського державного університету

\title{
КОМПЕТЕНТНІСНИЙ ПІДХІД ЯК КОНЦЕПТУАЛЬНА ОСНОВА ПІДГОТОВКИ МАЙБУТНІХ УЧИТЕЛІВ ПОЧАТКОВОЇ ШКОЛИ
}

У статті проаналізовано сучасні підходи до формулювання поняття “компетентність". Історикотермінологічний аналіз його сутності дав можливість з'ясувати складові, структуру фаховоі компетентності. Особлива увага акиентується на змісті ключових та предметних компетентностях. Формування професійної компетентності майбутніх учителів початкової школи необхідно здійснювати з урахуванням сучасних вимог в галузі освіти, освітніх програм спеціальності, враховуючи Державний стандарт початкової загальної освіти.

Ключові слова: компетентність, компетентнісний підхід, професійна компетентність, учитель початкової школи, освітній прочес.

Jim. 9.

Oksana Liba, Ph.D.(Pedagogy), Senior Lecturer of the Theory and Methodology of Elementary Education Department Mukachevo State University

\section{COMPETENCE APPROACH AS A CONCEPTUAL FRAMEWORK OF THE PREPARATIONS OF FUTURE TEACHERS OF THE PRIMARY SCHOOL}

The cardinal changes are taking place in the social and economic sphere of the state, the entry of Ukrain into the world educational space determines the innovation processes, reorientation of vocational and pedagogical preparation to European standards. In this regard, the requirements have been increased not only to the professional competence of the teacher, but also to personal qualities, manifested in the ability to navigate in the diversity of contradictions of the modern world, be prepared for permanent changes, independently acquire competences in accordance with the chosen specialty, identify the personal ways of creative selfrealization, self-development and self-education.

Modernization of Ukrainian educational system takes place in line with democratic social transformations and the priorities of the present days, which necessitate the substantial updating of the content, forms and methodical provision of training of specialists on the basis of a competent approach. This is provided by the Law of Ukraine "On Education", the Concept "New Ukrainian School".

The competence approach is the basis of formation of competitiveness of the future specialist. Competitiveness has the attributes of competency that allows to evaluate knowledge, skills and experience, as well as experiences and values acquired through the process of training in a higher education institution.

The purpose of the research is to analyze the modern approaches to the formulation of the concept "competence", to find out the components of professional competence.

The modern approaches to the formulation of the concept "competence" have been analyzed in the article. The historical and terminological analysis of its essence made it possible to find out the components, the structure of professional competence. The special attention has been paid to the content of key and substantive competencies. Formation of professional competence of future teachers of elementary school should be carried out taking into account the modern requirements in the field of education, educational programs of the specialty, and the State standard of elementary general education.

Keywords: competence, a competence approach, professional competence, a teacher of elementary school, an educational process.

П остановка проблеми. Кардинальні зміни, що відбуваються в суспільноекономічній сфері держави, входження України в світовий освітній простір детермінує інноваційні процеси, переорієнтацію професійнопедагогічної підготовки на європейські стандарти. У зв'язку з цим посилюються вимоги не тільки до професійної компетентності вчителя, а й до його особистісних якостей, що виявляються в здатності орієнтуватися в розмаїтті протиріч сучасного світу, бути готовим до перманентних змін, самостійно набувати компетенцій згідно 3 обраним фахом, визначати особистісні способи творчої самореалізації, саморозвитку й самоосвіти.

Модернізація освітньої системи України відбувається згідно 3 демократичними соціальними перетвореннями і пріоритетами сьогодення, які зумовлюють потребу суттєвого 


\section{КОМПЕТЕНТНІСНИЙ ПІДХІД ЯК КОНЦЕПТУАЛЬНА ОСНОВА}

\section{ПІДГОТОВКИ МАЙБУТНІХ УЧИТЕЛІВ ПОЧАТКОВОӤ ШКОЛИ}

оновлення змісту, форм і методичного забезпечення підготовки фахівців на засадах компетентнісного підходу. Це передбачено Законом України "Про освіту” [4], Концепцією “Нова українська школа".

Аналіз останніх досліджень і публікацій. Різні аспекти компетентнісного підходу досліджували: Т. Байбара, Н. Бібік [1], О. Бобієнко, Т. Браже, Л. Ващенко, І. Зимня, В. Краєвський, О. Локшина, О. Овчарук, О. Онопрієнко, С. Остапенко, О. Пометун [8], О. Савченко, Г. Терещук, А. Хуторський та інші.

Проблему компетентнісного підходу як методологічну основу збереження цілей, змісту і якості вищої освіти розглядали:Дж. Боуден,А. Бермусм, М. Лейтер, Дж. Равен, Е. Шорт та ін. Теорію формування ціннісних орієнтацій розроблено в дослідженнях О. Арнольдова, І. Беха, Е. Ільєнкова, М. Кагана, В. Межуєва та ін.

Українські вченіН. Бібік, О. Локшина, О. Овчарук, О. Пометун, О. Савченко та ін. визначили сукупність ключових компетентностей майбутнього фахівця: уміння вчитись; громадянську; загальнокультурну; компетентність 3 інформаційних та комунікаційних технологій; соціальну; підприємницьку; здоров'язберігаючу. Перелік компетентностей випускника як професіонала буде змінюватися в залежності від потреб суспільства і держави у процесі ії̈ розвитку, але ключові компетентності, такі як навчальна, громадянська, загальнокультурна, комунікативна, соціальна, підприємницька, здоров'язберігаюча $\epsilon$ постійними і мають бути сформовані у сьогоднішніх випускників вищих навчальних закладів [5, 159].

Основна увага вчених акцентується на компетенціях, що сприяють адаптації фахівців до умов сучасного ринку праці. Сьогодні компетентнісний підхід стає невід'ємним складником освітньої галузі.

Постановка завдання. На основі викладеного можна сформулювати завдання дослідження, які полягають у визначенні та обгрунтуванні аргументів про те, що компетентнісний підхід $\epsilon$ базовим для формування конкурентноздатності майбутнього фахівця. Конкурентноздатність носить ознаки компетентності, що дає змогу оцінити як знання, уміння й навички, так досвід та цінності, які набуті в процесі професійної підготовки у вищому навчальному закладі.

Мета дослідження - проаналізувати сучасні підходи до формулювання поняття “компетентність”, з'ясувати складові фахової компетентності.

Виклад основного матеріалу дослідження. Сучасна орієнтація освіти України на європейські цінності удосконалює законодавчу базу в цій галузі, так як сьогодні потрібні компетентні спеціалісти, які не тільки мають професійні знання, уміння та навички, але й можуть приймати відповідальні рішення в ситуаціях вибору, схильні до співробітництва, вирізняються мобільністю, конструктивністю, здатністю до адаптації, умінням реалізувати свій творчий потенціал. Сьогодні мають місце три підходи (три моделі), на основі яких можна аналізувати й розбудовувати освітній процес у сучасній школі.

1. Підхід з погляду змісту. Головним $є$ те, “що викладається учням в школі”, навчальний план (навчальні програми) є набором “знаннєвих" можливостей учня, які можуть бути реалізовані на уроках і в позаурочний час.

2. Підхід 3 погляду процесу навчання. Основними питаннями стають: що відбувається під час навчання? Як учні вчаться? Що насправді вони засвоюють 3 викладеного? Аналізові підлягають “реальні” явища та процеси, що відбуваються в класі, коли учні разом з учителем здійснюють пізнавальну діяльність в класі чи поза ним.

3. Підхід з погляду результатів. Такий підхід спрямовує на цілий набір компетентностей (знань, умінь, навичок, ставлень тощо), котрими оволоділи учні, які закінчують школу $[7,16]$.

Водночас зазначено, що важливим сьогодні $є$ набуття учнем набору життєвих компетентностей, необхідних для життя в суспільстві та швидкозмінному світі. Як економічні, соціальні, так і інші чинники розвитку цивілізації посилили зацікавленість суспільства результатами освіти і зумовили появу (поруч із традиційними: кількість років навчання, здобуття певного ступеня освіти) нових, важливіших і реальніших, індикаторів цих результатів. Такими індикаторами сьогодні, разом 3 тим, що особа знає і вміє в шкільних предметах, $\epsilon$ їі здатність відповідати вимогам сучасного життя. Якщо у 80-х роках XX століття розвинені країни тільки розпочали обговорювати прагматичні підходи до навчання, то останніми роками можна спостерігати систематичні зусилля в цьому напрямі. Такими індикаторами в багатьох країнах стали саме компетентності, що визначають готовність учня до життя, його участі в житті суспільства.

Результати багаторічної роботи експертів країн Європейського Союзу в цьому напрямі свідчать, що:

- для будь-якої країни корисно порівнювати міжнародний і національний досвіди як розвитку освітньої системи загалом, так і можливостей для запровадження комптентнісного підходу зокрема; 


\section{КОМПЕТЕНТНІСНИЙ ПІДХІД ЯК КОНЦЕПТУАЛЬНА ОСНОВА}

\section{ПІДГОТОВКИ МАЙБУТНІХ УЧИТЕЛІВ ПОЧАТКОВОЇ ШКОЛИ}

- повне копіювання будь-яких освітніх моделей і феноменів інших країн є непродуктивним;

- національні моделі освіти слід розбудовувати, керуючись національними потребами і особливостями $[7,16]$.

3 метою всебічного вивчення сутності і структури професійної компетентності як базової основи формування педагогічної майстерності майбутніх учителів початкових класів проведено історично-термінологічний аналіз поняття “компетентність”, який свідчить, що в педагогічних наукових колах цей термін почав застосовуватися $з$ вісімдесятих років XX ст. у значенні освітній результат діяльності особи, яка навчається.

Компетентність, за визначенням О. Пометун, потрібно сприймати як об'єктивну категорію, що фіксує суспільно визнаний комплекс певного рівня знань, умінь, навичок, ставлень, завдяки яким педагог здатний здійснювати складні поліфункціональні, поліпредметні, культуродоцільні види діяльності [8, 19].

Найбільш грунтовно в педагогічній науці розмежувала зазначені поняття стосовно вищої школи О. Заблоцька $[3,54]$. На основі контентаналізу вона прийшла до висновку, що:

- компетентність - це якість реалізації на практиці результату формування в суб'єктів навчання компетенцій, визначених нормативними джерелами для певної галузі діяльності (якість реалізації кваліфікації);

- кваліфікація - це офіційне визнання результату формування в суб'єктів навчання компетенцій, визначених нормативними освітніми документами для певної галузі діяльності;

- компетенції є одиницями та результатом освітньої діяльності при компетентнісному підході;

- компетенція - це інтегрована особистіснодіяльнісна категорія, яка формується під час навчання в результаті поєднання початкового особистого досвіду, знань, умінь, навичок, способів діяльності, особистісних цінностей та здатності їх застосування в процесі продуктивної діяльності стосовно кола предметів та процесів певної галузі людської діяльності $[3,55]$.

У процесі визначення вимог до педагогівпрактиків широко застосовується термін “професійна компетентність" як готовність і здатність фахівця приймати ефективні рішення при здійсненні професійної діяльності $[8,11]$.

Людина $є$ компетентною не сама по собі, а відносно реалізаціїзовнішніх функцій, тобто успішно функціонує увідповідь на індивідуальні або соціальні вимоги, здійснює діяльність або виконує задачі.
Професійна компетентність має свою структуру та класифікаційні ознаки. О. Дубасенюк до основних складових елементів професійнопедагогічної компетентності відносить: компетентність у сфері теорії та методики виховного процесу; компетентність у сфері фахових предметів; соціально-педагогічну компетентність; диференціально-психологічну компетентність; аутопсихологічну компетентність $[2,95]$.

I. Лернер, В. Краєвський, А. Хуторський пропонують розглядати кожну компетентність як єдність трьох складових:

- когнітивна складова (наявність системи педагогічних і спеціальних предметних знань);

- операціонально-технологічна складова (володіння методами, технологіями, способами педагогічної взаємодії, методами навчання даного предмета);

- особистісна складова (етичні й соціальні позиції й установки, риси особистості спеціаліста) [6, 109].

А. Маркова виділяє такі види професійної компетентності:

- спеціальна компетентність - володіння власне професійною діяльністю на досить високому рівні, здатність проектувати свій подальший професійний розвиток;

- соціальна компетентність - володіння спільною (груповою, кооперативною) професійною діяльністю, співробітництвом, а також прийнятими в даній професії прийомами професійного спілкування, соціальна відповідальність за результати своєї професійної праці;

- особистісна компетентність - володіння прийомами особистісного самовираження та саморозвитку засобами протистояння професійним деформаціям особистості;

- індивідуальна компетентність - володіння прийомами самореалізації i розвитку індивідуальності в межах професії, готовність до професійного зростання, вміння раціонально організувати свою працю без перевантажень [6, 107].

Педагоги, котрі працюватимуть у початковій школі, повинні використовувати весь арсенал умінь і навичок педагогічної майстерності для цілеспрямованої роботи з учнями молодших класів у зазначеному напрямі. Готовність до такої діяльності формується в майбутніх учителів ще під час навчання у вищій школі. Відтак, щоб системно й ефективно спрямовувати навчальнопізнавальну діяльність молодших школярів на формування конкретних компетентностей, в учителів початкової школи доцільно сформувати 


\section{КОМПЕТЕНТНІСНИЙ ПІДХІД ЯК КОНЦЕПТУАЛЬНА ОСНОВА}

\section{ПІДГОТОВКИ МАЙБУТНІХ УЧИТЕЛІВ ПОЧАТКОВОЇ ШКОЛИ}

відповідні компетентності в процесі здобуття вищої освіти, що розглядаємо як обов'язкову складову їхньої педагогічної майстерності. До таких компетентностей відносяться:

Громадянська компетентність - це здатність людини активно, відповідально та ефективно реалізовувати права й обов'язки з метою розвитку демократичного суспільства.

Ключова компетентність - спеціально структурований комплекс якостей особистості, що дає можливість ефективно брати участь у різних життєвих сферах діяльності і належить до загальногалузевого змісту освітніх стандартів. Розуміння ключової компетентності тісно пов'язане з поняттям “ключова компетенція”. Цей феномен розглядається як об'єктивна категорія, що фіксує суспільно визначений комплекс певного рівня знань, умінь, навичок, ставлень, які можна застосувати в широкій сфері діяльності людини (уміння вчитися, загальнокультурна, громадянська, здоров' язбережувальна, соціальна компетентність та компетентність 3 питань інформаційно-комунікаційних технологій).

Предметна компетентність - освоєний учнями у процесі навчання досвід специфічної для певного предмета діяльності, пов'язаної 3 набуттям нового знання, його перетворенням i застосуванням. Сформованість предметної компетентності передбачає вияв в особи предметної компетенції - сукупності знань, умінь та характерних рис у межах конкретного предмета, що дає можливість учневі (а також і вчителеві початкової школи) самостійно виконувати певні дії для розв’ язання навчальної проблеми (задачі, ситуації). Як учень, так і вчитель відповідно до власного рівня підготовки, має уявлення, знає, розуміє, застосовує, виявляє ставлення, оцінює.

Предметна компетентність майбутнього вчителя початкових класів передбачає його готовність формувати в молодших школярів такі види компетентностей, як:

1) предметна математична компетентність особистісне утворення, що характеризує здатність учня створювати математичні моделі процесів навколишнього світу, застосовувати досвід математичної діяльності під час розв'язування навчально-пізнавальних і практично зорієнтованих задач;

2) природознавча компетентність - особистісне утворення, що характеризує здатність учня розв'язувати доступні соціально й особистісно значущі практичні та пізнавальні проблемні задачі, пов’ язані з реальними об'єктами природи у сфері відносин "людина - природа";

3) комунікативна компетентність - здатність особистості застосувати у конкретному спілкуванні знання мови, способи взаємодії $з$ навколишніми і віддаленими людьми та подіями, навички роботи в групі, володіння різними соціальними ролями.

Оскільки майбутній учитель початкових класів навчає молодших школярів кільком предметам, відтак і в учня, і в майбутнього вчителя необхідно формувати міжпредметну компетентність здатність особи застосувати щодо міжпредметного кола проблем знання, уміння, навички, способи діяльності та ставлення, які належать до певних навчальних предметів і предметних галузей.

Окрім цього, в Державному стандарті початкової загальної освіти наголошується на необхідності формування міжпредметних естетичних компетентностей - здатності орієнтуватися в різних сферах життєдіяльності, що формується під час опанування різних видів мистецтва. Предметними мистецькими компетентностями, в тому числі музичними, образотворчими, хореографічними, театральними, екранними, є здатність до пізнавальної та практичної діяльності у певному виді мистецтва, що необхідно для вчителя початкових класів для організації ефективного навчально-виховного процесу з молодшими школярами. Цей вид компетентності тісно пов'язаний із соціальною компетентністю - здатністю особистості продуктивно співпрацювати з партнерами в групі та команді, виконувати різні ролі та функції у колективі. У цьому контексті слушним $\epsilon$ поєднання науковцями професійної та соціальної компетентностей у соціально-професійну.

Зазвичай, зазначені поняття $є$ засадничими у реалізації компетентнісного підходу, що визначається у Державному стандарті як спрямованість навчально-виховного процесу на досягнення результатів, якими $є$ такі ієрархічнопідпорядковані компетентності учнів: ключова, загальнопредметна і предметна. У результативній складовій кожної освітньої галузі Державного стандарту початкової загальної освіти визначено державні вимоги до рівня загальноосвітньої підготовки учнів початкової школи, які відповідають змісту і структурі предметних компетентностей. У Державному стандарті початкової загальної освіти зазначається, що протягом навчання у початковій школі учні повинні оволодіти ключовими компетентностями, які передбачають їх особистісно-соціальний та інтелектуальний розвиток, формуються на міжпредметній основі та $\epsilon$ інтегрованим результатом предметних і міжпредметних компетенцій. Сьогодні Міністерство освіти і науки 


\section{КОМПЕТЕНТНІСНИЙ ПІДХІД ЯК КОНЦЕПТУАЛЬНА ОСНОВА ПІДГОТОВКИ МАЙБУТНІХ УЧИТЕЛІВ ПОЧАТКОВОЇ ШКОЛИ}

розробляє навчальні програми, відповідно до яких створюються варіативні програми і підручники, а також здійснюється цілеспрямована підготовка майбутніх учителів початкових класів на педагогічних засадах формування у них компетентності саморозвитку фахівця для роботи 3 молодшими школярами. Однак, окреслені в Державному стандарті компетентності здебільшого відносяться до навчання молодших школярів. А формування педагогічної майстерності майбутніх учителів початкових класів потребує більш розширеного комплексу компетентностей. Передбачається, що вони визначатимуть професійну компетентність учителя як базово-об'єднуючу основу формування педагогічної майстерності майбутніх учителів початкових класів $[9,380]$.

Висновки $з$ проведеного дослідження. Таким чином, нами з'ясовано поняття “компетентність”, “фахова компетентність” та визначено їх складові. Нами визначено, що розв'язати проблему забезпечення нового освітнього результату саме покликаний компетентнісний підхід.

У подальшому дослідженні нами буде обгрунтовано процес формування конкурентноздатності в майбугніх учителів початкових класів.

\section{ЛITEPAТУРА}

1. Бібік Н.М. Компетентнісний підхід: рефлексивний аналіз застосування [Текст] / Н.М. Бібік // Компетентнісний підхід у сучасній освіті: світовий досвід та українські перспективи: Бібліотека $з$ освітньої політики / [За заг. ред. О.В. Овчарук]. K.: K.I.C., 2004. - C. 47-52.

2. Дубасенюк О.А. Кониептуальні положення теоретичноїпрофесійноїдіяльності [Текст] /O.А. Дубасенюк // Педагогіка і психологія. - 1994. - № 4. - С. 94-97.

3. Заблоиька О.С. Компетентність, кваліфікаиія, компетенція як ключові категорії компетентнісної парадигми вищої освіти [Текст] / О.С. Заблоиька // Вісник Житомирського державного університету імені Івана Франка. - 2008. - № 39. - С. 52-56.

4. Закон України "Про освіту"-Режим доступу http://zakon2.rada.gov.ua/laws/show/2145-19

5. Зубчевська С. Проблема формування загальнокультурної компетентності у студентів аграрного коледжу / С. Зубчевська // Збірник наукових праць Уманського державного педагогічного університету. - 2013. Ч. 2. C. 158-163. Режим достуny: http://nbuv.gov.ua/ UJRN/znpudpu_2013_2_22.

6. Іванова С.В. Функиіональний підхід до визначення професійної компетентності вчителя біології та організачія ії вдосконалення в закладі післядипломної освіти [Текст] / С.В. Іванова // Вісник Житомирського державного університету імені Івана Франка. Серія: педагогічні науки. -2008.-Bип. 42. - C. $106-110$.

7. Компетентнісний підхід у сучасній освіті: світовий досвід та украӥнські перспективи: Бібліотека з освітньої політики / Під заг. ред. О.В.Овчарук. - K.: “К.I.C.”, 2004. - 112 c.

8. Пометун О.І. Формування громадянськоӥ компетентності: погляд з позичї сучасної педагогічної науки [Текст] /О. І. Пометун // Вісник програм шкільних обмінів. - 2005. - № 23. - С. 18-20.

9. Теличко Н.В. Професійна компетентність як базова основа педагогічної майстерності вчителя початкових класів / Н. В. Теличко // Науковий вісник Національного університету біоресурсів $i$ природокористування України. Серія: Педагогіка, психологія, філософія. - 2014. - Вип. 199(1). C. 376-383. - Режим достуny: http://nbuv.gov.ual UJRN/nvnau ped 2014 199(1) 61.

\section{REFERENCES}

1. Bibik, N.M. (2004). Kompetentnisnyi pidkhid: refleksyvnyi analiz zastosuvannia [Competency approach: reflexive application analysis]. Kompetentnisnyi pidkhid u suchasnii osviti: svitovyi dosvid ta ukrainski perspektyvy: Biblioteka z osvitnoi polityky [Competency Approach in Modern Education: World Experience and Ukrainian Perspectives: Library of Educational Policy]. O.V. Ovcharuk (Ed.). Kyiv: K.I.S., pp. 47-52.[in Ukrainian].

2. Dubaseniuk, O.A. (1994). Kontseptualni polozhennia teoretychnoi profesiinoi diialnosti [The conceptual provisions of theoretical professional activity]. Pedagogy and Psychology, no. 4, pp. 94-97.[in Ukrainian].

3. Zablotska, O.S. (2008). Kompetentnist, kvalifikatsiia, kompetentsiia yak kliuchovi katehorii kompetentnisnoi paradyhmy vyshchoi osvity [Competence, qualification, competence as key categories of competency of higher education paradigm]. The bulletin of Zhytomyr Ivan Franko State University,no.39, pp. 52-56.[in Ukrainian].

4. Zakon Ukrainy "Pro osvitu" [Law of Ukraine "On Education"]. Available at: http://zakon2.rada.gov.ua/laws/ show/2145-19 [in Ukrainian].

5. Zubchevska, S. (2013). Problema formuvannia zahalnokulturnoi kompetentnosti u studentiv ahrarnoho koledzhu [The problem of formation of general cultural competence among students of the agrarian college]. A Collection of scientific works of Uman State Pedagogical University, part 2, pp. 158-163. Available at: http://nbuv.gov.ua/UJRN/ znpudpu_2013_2_22. [in Ukrainian].

6. Ivanova, S.V. (2008). Funktsionalnyi pidkhid do vyznachennia profesiinoi kompetentnosti vchytelia biolohii ta orhanizatsiia yii vdoskonalennia $v$ zakladi pisliadyplomnoi osvity [Functional approach to the definition of the professional competence of the teacher of biology and the organization of its improvement in the institution of postgraduate education]. A bulletin of Zhytomyr Ivan Franko State University. Series: pedagogical sciences, vol. 4, pp. 106-110. [in Ukrainian].

7. Ovcharuk, O.V. (Ed.). Kompetentnisnyi pidkhid u suchasnii osviti: svitovyi dosvid ta ukrainski perspektyvy: Biblioteka $z$ osvitnoi polityky 
[Competency Approach in Modern Education: World Experience and Ukrainian Perspectives: Library of Educational Policy]. Kyiv: "K.I.S.”, 112 p. [in Ukrainian].

8. Pometun, O.I. (2005). Formuvannia hromadianskoi kompetentnosti: pohliad $z$ pozytsii suchasnoi pedahohichnoi nauky [The formation of civic competence: a view from the standpoint of modern pedagogical science]. The herald of School Exchange Programs, no. 23, pp. 18-20. [in Ukrainian].
9. Telychko, N.V. (2014). Profesiina kompetentnist yak bazova osnova pedahohichnoi maisternosti vchytelia pochatkovykh klasiv [Professional competence as a base of pedagogical mastery of teachers of elementary school]. The scientific herald of the National University of Bioresources and Nature Management of Ukraine. Series: Pedagogy, Psychology, Philosophy. Vol. 199(1), pp. 376-383. Available at: http://nbuv.gov.ua/UJRN/ nvnau_ped_2014_199(1)_61. [in Ukrainian].

Стаття надійшла до редакції 01.02.2018

УДК 784.4(477.83 - 25) “18 - 19”

Андрій Ковбасюк, кандидат мистеитвознавства, доцент кафедри музикознавства та хорового мистецтва факультету культури і мистеитв Львівського національного університету імені Івана Франка

\section{СПАДКОСМНІСТЬ ПІСЕННО-ФОЛЬКЛОРНОЇ ТРАДИЦІЇ В МУЗИЧНОМУ ЖИТТІ ЛЬВОВА КІНЦЯ ХІХ - ХХ СТОЛІТЬ}

Розкрито пісенно-фольклорну складову львівської музичної культури кіния ХІХ - ХХ століть. Виокремлено осередки популяризаиї̈ народної пісні у Львові. Висвітлено український пісенний фольклор як засіб наиіонально-суспільного самовираження. Зроблено історичний аналіз розвитку музичного життя Львова кінці XIX-XX століть в контексті української пісенно-фольклорної традиції. Визначено, щэо рівень пісенної культури народу Галичини є яскравим показником його загального духовного розвитку.

Ключові слова: украӥнська народна пісня, пісенно-фольклорна традиція, музична культура, музичне життя Львова.

תim. 5.

Andriy Kovbasyuk, Ph.D.(Art Studies), Associate Professor of the Musicology and Choral Art Department Faculty of Culture and Arts Lviv Ivan Franko National University

\section{SUCCESSION OF THE MUSIC AND FOLK TRADITIONS OF LVIV MUSICAL LIFE LATE XIX - XX CENTURY}

The song and folklore component of the Lviv musical culture at the end of the 19th and 20th centuries is revealed. The song and folklore component of the musical life of Lviv at the end of the 19th and 20th centuries was presented in many directions, namely: in artistic and stage activities, performing interpretations, composer stylistics and in the musical and educational sphere. The Ukrainian song folklore as a means of national-social expression is highlighted. The self-awareness of the Ukrainian nation for centuries has been exerted in the musical arts (most in the song's creation) as a form of the national and social expression. Thanks to this fact, Ukrainians managed to survive as a nation and not to lose their culture. Ukrainian singing was also used as a form that provided the ample opportunity for the realization of the educational aspirations of the Galician intelligentsia. A historical analysis of the development of musical life of Lviv at the end of the 19th and 20th centuries in the context of the Ukrainian song and folklore tradition was made. It is determined that the level of song culture of the people of Galicia is a vivid indicator of its general spiritual development. Lviv.

Keywords: Ukrainian national song, the music and folk traditions, the music culture, the music life of

П остановка проблеми. Народну культуру та мистецтво українців слушно вважають одними 3 найбагатших надбань культурної спадщини $\epsilon$ вропейських націй. Відомо, що українська культура володіє розкішною пісенною спадщиною, яка породжена фольклорною традицією та опосередкована через творчість великої кількості мистців. Саме 3 цієї причини вивчення впливу народної пісні на формування регіональної музичної культури має важливе значення і є актуальним об'єктом наукових розвідок.

Попри всі відмінності в мистецькому розвитку різних регіонів України, друга половина XIX століття всюди позначена опануванням i переосмисленням “інтонаційних кодів" української народної пісні упрофесійній музичній культурі. Відбувається процес формування глибоко народного й реалістичного мистецтва. 